\title{
Role of Organic Spices in the Preservation of Traditionally Fermented Kunun-zaki
}

\author{
Williana, N. Mokoshe, Babasola, A. Osopale, Cajethan, O. Ezeamagu, and Stephen O. Fapohunda* \\ Department of Microbiology, School of Science and Technology, Babcock University, Ilishan-Remo, Ogun State, Nigeria
}

Received: June 16, 2020 / Revised: December 22, 2020 / Accepted: December 23, 2020

\begin{abstract}
Kunun-zaki, produced by submerged fermentation of a combination of millet and sorghum, is a popular beverage in Northern Nigeria. Owing to the nature of the process involved in its production, kunun-zaki is highly susceptible to contamination by food spoilage microorganisms, leading to inconsistent quality and short shelf-life. In this study, we investigated various food spices, including cinnamon, garlic, and nutmeg, as potential preservatives that could be used to extend kunun-zaki shelf-life. Kunun-zaki varieties were fermented with each of these spices mentioned above and subjected to bacterial, nutritional, sensory, and quality maintenance assessments (using a twelve-member sensory panel to evaluate the organoleptic properties of kunun-zaki). Bacterial counts in the final products ranged between $10^{5-7} \mathrm{CFU} / \mathrm{ml}$. We identified two bacterial genera, Weissella and Enterococcus, based on partial 16S rRNA gene amplicon sequencing. Three amino acids, namely leucine, aspartate, and glutamate, were abundant in all kunun-zaki varieties, while the total essential amino acid content was above $39 \%$, suggesting that kunun-zaki could potentially be considered as a protein-rich food source both for infants and adults. The kunun-zaki products were also rich in carbohydrates, crude proteins, ash, crude fiber, and fat, with contents estimated as 81-84, 8-11, 0.8-4.0, 2.93.58, and 5.1-6.3\%, respectively. However, this nutritional content depreciated rapidly after $24 \mathrm{~h}$ of storage, except for kunun-zaki fermented with garlic, which its crude protein and fat content was maintained for up to $48 \mathrm{~h}$. Our results revealed that organic spices increased the nutritional content of the kunun-zaki varieties and could be potentially be used as natural preservatives for enhancing the kunun-zaki shelf-life. However, garlic might be considered a better alternative based on our preliminary investigation. The presence of the isolated microorganisms in the analyzed kunun-zaki samples should be highlighted to raise awareness on the possible health hazards that could arise from poor handling and processing techniques.
\end{abstract}

Keywords: Kunun-zaki, food spices, shelf-life

\section{Introduction}

Kunun-zaki is a popular beverage in northern Nigeria, and is produced by submerged fermentation of millet (Pennisetum glaucum), sorghum (Sorghum bicolor) or maize (Zea mays), in decreasing order of preference or a combination of at least two grain substrates [1-3]. Ingredients also included in kunun-zaki are sweeteners (honey or sugar), sweet potatoes and spices such as

\footnotetext{
*Corresponding author

Tel: +2348033709492

E-mail: fapohundas@babcock.edu.ng
}

ginger, cloves or black pepper [4,5]. Kunun-zaki is an important beverage because it is an inexpensive source of vitamins, minerals, carbohydrates and proteins, for large population in Nigeria [6-9]. There has been a report that production methods of kunun-zaki are crude, with ingredients neither quantified nor standardized, leading to products of varying quality and consistency [1]. Most importantly, lack of control over the entire production processes makes kunun-zaki highly susceptible to contamination with pathogenic and food spoilage bacteria [10].

Lactic acid bacteria (LAB) have been reported as the dominant species isolated from kunun-zaki and there- 
fore, its fermentation is considered as the major contributor to the beneficial characteristics observed in kununzaki [11-13]. There has been report of microbial contamination at various stages of production [8] as processing is usually carried out under unhygienic conditions, thus, predisposing the final kunun-zaki to microbial pathogens $[9,14]$. Noted that the spices used for making kunun-zaki microbial contamination while [9] reported that locally prepared beverages may serve as vehicles for zoonotic and food-borne diseases such as Staphylococcosis, salmonellosis, brucellosis, tuberculosis, Listeriosis, and shigellosis.

Organic additives as spices are generally used as flavouring, colouring, and preservation agents in food or beverages [15]. Many of these spices possess antimicrobial effects, and are derives from plant essential (volatile) oils which disrupt microbial cell membrane integrity, by negatively affecting the $\mathrm{pH}$ homeostasis and inorganic ions [16, 17]. This phenomenon has been associated with the volatile oils of black pepper, cloves, granium, nutmeg, oregano and thyme in their antimicrobial activities against Enterococcus faecalis, Escherichia coli, Salmonella pullorum, Staphylococcus aureus and Yersinia enterocolitica [18]. In addition, cinnamon volatile oils and their active compounds (cinamaldehyde and eugenol) have also shown antimicrobial activities against $E$. coli, Pseudomonas aeruginosa, E. faecalis, S. aureus, Staphylococcus epidermidis, Klebsiella pneumoniae, Salmonella sp. and Vibrio parahaemolyticus [19]. In vitro antimicrobial effects have also been attributed to many other volatile oils, including garlic, black cumin seeds, lemon grass, onions and laurel [20].

The current study assessed the impact of three readily available and affordable organic spices; garlic (Allium sativum), cinnamon (Cinnamomum verum) and nutmeg (Myristica fragrans), on the shelf-life and nutritional profile of kunun-zaki products, as potential preservatives in Kunun-zaki products.

\section{Materials and Methods}

\section{Ethical clearance}

Ethical clearance was obtained from Babcock University Health Research Ethics Committee (BUHREC) with ref number NHREC/24/01/2018.

\section{Preparation of Kunun-zaki varieties under laboratory con- ditions}

Kunun-zaki ingredients, including sorghum, millet, sweet potatoes (Ipomea batatas) and organic spices, including ginger (Zingiber officinale), cloves (Syzygium aromaticum), black pepper (Piper nigrum), garlic, cinnamon, and nutmeg were all purchased from the central market in Ilishan-Remo, Nigeria. Kunun-zaki was prepared in the laboratory according to the traditional fermentation method, described by [21] with slight modification. Briefly, $250 \mathrm{~g}$ of a mixture of millet and sorghum (ratio 4:1) was cleaned by manually removing stones and plant debris. The grains were then washed thoroughly with sterile distilled water, followed by steeping in $500 \mathrm{ml}$ sterile distilled water (1: $2 \mathrm{w} / \mathrm{v})$ for $3 \mathrm{~h}$ in a sterile $1000 \mathrm{ml}$ beaker. The water was decanted and the grains washed with $500 \mathrm{ml}$ sterile distilled water. The soaked grains were separated from the water and then wet milled into paste using an electric blender (NL-B1218 NULEK, New life, Japan). The paste was divided into two unequal parts in ratio $1: 3(\mathrm{v} / \mathrm{v})$ and $500 \mathrm{ml}$ boiling hot water was then added to the larger portion to gelatinize, while the smaller portion was mixed with blended $5.5 \mathrm{~g}$ sweet potato, $1 \mathrm{~g}$ black pepper, $1 \mathrm{~g}$ cloves, $1 \mathrm{~g}$ ginger and $5 \mathrm{~g}$ of either garlic, nutmeg or cinnamon. The smaller paste portion was added to the larger portion when the latter's was tempered to about $25^{\circ} \mathrm{C}$. The mixture was stirred using a sterile glass rod and allowed to ferment for $12 \mathrm{~h}$ at room temperature. Subsequently, the samples were filtered using a sterile muslin cloth and the filtrate was the Kunun-zaki product. Three replicas of this fermentation was carried out.

\section{Bacteriological assessment of kunun-zaki varieties}

The bacterial composition of each Kunun-zaki variety at two critical control points (CCPs) was assessed by culture-dependent approach. The CCPs assessed included the grain-washing steps and the finished kunun-zaki products. One milliliter of sample was diluted in $9 \mathrm{ml}$ sterile peptone water up to $10^{-5}$ dilution and pour plated on nutrient agar (NA) (Oxoid Basingstoke, UK) and De Man, Rogosa Sharpe (MRS) Agar (Hi Media, India). The plates were incubated at $37^{\circ} \mathrm{C}$ for $24 \mathrm{~h}$, and colonies were recorded as colony forming units per $\mathrm{ml}(\mathrm{cfu} / \mathrm{ml})$ of 
sample. Distinct colonies on MRS agar were selected and re-streaked to obtain pure cultures, and were preserved in $15 \%$ glycerol.

The identity of bacterial isolates was determined by $16 \mathrm{~S}$ rRNA gene sequencing. Genomic DNA of isolates was extracted Qick-DNA ${ }^{\mathrm{TM}}$ miniprep plus kit (Zymo research, Biolab, USA) following the manufacturer's instruction. The DNA was subsequently amplified by PCR using the primers 341F (5'-CCTACGGGAGGCAGCAG3-3') and R806 (5'-GGACTACHVGGGTWTCTAAT3-3'). Each PCR was $25 \mu \mathrm{l}$, containing; $12 \mu \mathrm{l}$ PCR Master Mix (New England Biolabs), $1 \mu \mathrm{l}$ template DNA, $10 \mu \mathrm{l}$ sterilized distilled water and $1 \mu \mathrm{l}$ of each primer. Thermo-cycling conditions were initial denaturation at $95^{\circ} \mathrm{C} / 5 \mathrm{~min}$, followed by 30 cycles of denaturation at $94^{\circ} \mathrm{C} / 30 \mathrm{~s}$, annealing at $50^{\circ} \mathrm{C} / 30 \mathrm{~s}$ and extension at $68^{\circ} \mathrm{C} / 5 \mathrm{~min}$, followed by a final extension step at $65^{\circ} \mathrm{C} / 5 \mathrm{~min}$. The amplicons were resolved in $1.5 \%$ agarose gel stained with $0.1 \mu \mathrm{g} / \mathrm{ml}$ ethidium bromide. The amplicons were then submitted for sequencing at Inqaba Biotechnical Industrial (Pty) Ltd, South Africa. The DNA sequences obtained were compared to the NCBI 16S rRNA gene database to determine close relatives, using the BLAST search algorithm. DNA sequence data were deposited in the GenBank under the accession numbers MT023719-MT023727.

\section{Nutritional evaluation of kunun-zaki varieties}

The physicochemical properties of the final kunun-zaki products were determined by measuring $\mathrm{pH}$, titratable acidity (TTA), and contents of moisture, ash, crude fiber, lipid, proteins, amino acids and carbohydrates, using the methods of [22].

\section{Sensory and shelf-life assessment of kunun-zaki varieties}

Kunun-zaki samples were either refrigerated or stored at ambient room temperature for 5 days. An informal sensory panel comprising male (8) and female (4) within the age range of 21-35 years was used to assess the quality attributes of the products; appearance, aroma, colour, taste, and overall acceptability at $12 \mathrm{~h}$ intervals. The $\mathrm{pH}$ of kunun-zaki samples was also determined intermittently with HI 2215 pH/ORP Meter (HANNA Instruments, Romania). For taste evaluation, panelists were requested to rinse their mouth with clean water between samples tasting; $15 \mathrm{ml}$ of the samples were served in clean transparent cups. The panelists' responses were recorded on a 7-points hedonic scale as recommended [23].

\section{Statistical analysis}

The effect of garlic, cinnamon and nutmeg on the $\mathrm{pH}$ of Kunun-zaki before and after fermentation, titratable acidity, and sensory quality were analyzed statistically with the aid of SPSS software version 21.0 using OneWay Analysis of Variance (ANOVA).

\section{Results and Discussion}

\section{Physicochemical properties of kunun-zaki varieties}

The $\mathrm{pH}$ of kunun-zaki before and after fermentation is presented in Fig. 1. Expectedly, $\mathrm{pH}$ reduced in all samples from 5.3-6.3 before fermentation to 4.1-5.2 after overnight fermentation. This may be attributed to acidification brought about by the formation of lactic acid, as previously observed by [24]. Titratable acidity, which measured the percentage of lactic acid in the kunun-zaki products, ranged between $0.0049 \mathrm{~g} / \mathrm{l}$ to $0.0063 \mathrm{~g} / \mathrm{l}$ signifying low TTA with poor production of lactic acid. This poor production invariably led to higher $\mathrm{pH}$ values (Table 1 ). These values were similar to those reported previously [25, 26]. However, it appeared that the samples containing cinnamon, garlic and nutmeg had a higher $\mathrm{pH}$ value and the control sample lacking these spices had the lowest $\mathrm{pH}$; indicating the presence

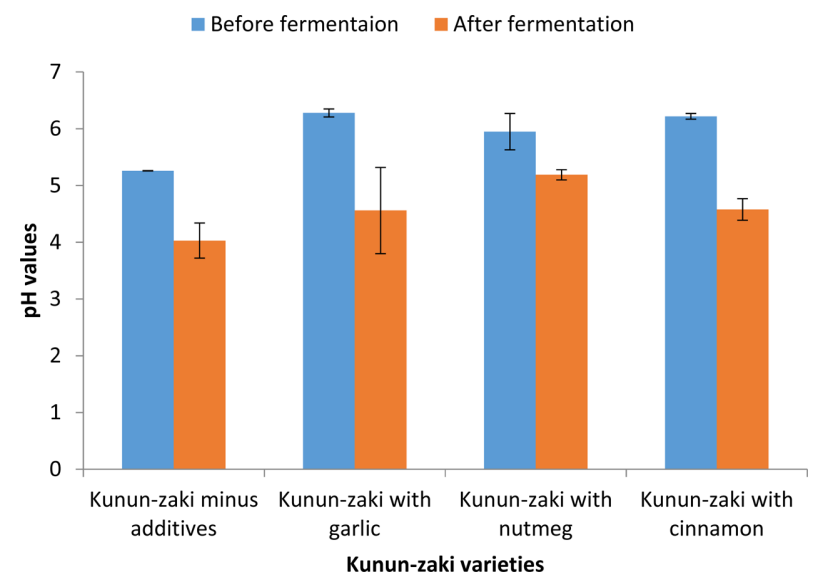

Fig. 1. pH values of kunun-zaki varieties recorded before and after substrate fermentation. Error bars indicate standard deviation of the mean of data obtained from duplicate independent experiments. 
Table 1. Titratable acidity and sensory qualities of different varieties of kunun-zaki fermented with organic spices.

\begin{tabular}{lcccc}
\hline \multirow{2}{*}{ Quality attributes } & \multicolumn{4}{c}{ Kunun-zaki varieties } \\
\cline { 2 - 5 } & $\mathrm{K} 1$ & $\mathrm{~K} 2$ & $\mathrm{~K} 3$ & $\mathrm{~K} 4$ \\
\hline Titratable acidity & $0.0055 \pm 0.00042$ & $0.0057 \pm 0.00031$ & $0.0063 \pm 0.00057$ & $0.0049 \pm 0.00027$ \\
Taste & $1.8 \pm 0.17^{\mathrm{a}}$ & $3.3 \pm 0.37^{\mathrm{b}}$ & $3.83 \pm 0.58^{\mathrm{c}}$ & $3.08 \pm 0.45^{\mathrm{d}}$ \\
Appearance & $1.33 \pm 0.14^{\mathrm{a}}$ & $3.25 \pm 0.37^{\mathrm{b}}$ & $3.17 \pm 0.51^{\mathrm{c}}$ & $2.42 \pm 0.29^{\mathrm{d}}$ \\
Aroma & $1.50 \pm 0.19^{\mathrm{a}}$ & $2.9 \pm 0.38^{\mathrm{b}}$ & $3.50 \pm 0.59^{\mathrm{c}}$ & $2.08 \pm 0.38^{\mathrm{d}}$ \\
Overall acceptability & $1.42 \pm 0.15^{\mathrm{a}}$ & $3.25 \pm 0.37^{\mathrm{b}}$ & $3.8 \pm 0.58^{\mathrm{c}}$ & $2.42 \pm 0.38^{\mathrm{d}}$ \\
\hline
\end{tabular}

${ }^{1} \pm$ standard deviation of 12-member taste panellist (7-point hedonic scale: 1-like extremely, 2-like very much, 3-like slightly, 4-n either like nor dislike, 5-dislike slightly, 6-dislike very much, 7-dislike extremely).

${ }^{2}$ Different letters within the same row are significantly different $(p<0.05)$.

K1- Kunun without any spice; K2- Kunun with cinnamon; K3- Kunun with garlic; K4- Kunun with nutmeg.

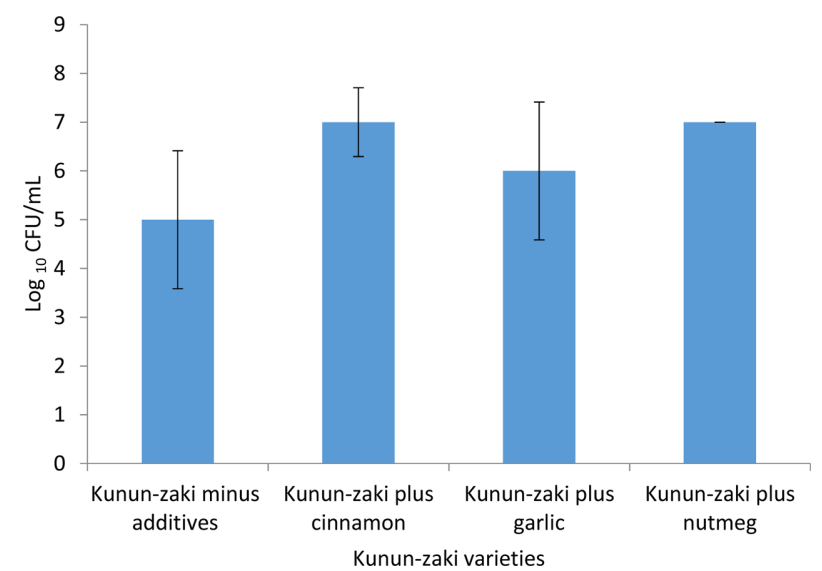

Fig. 2. Bacterial counts ( $\log _{10} \mathrm{CFU} / \mathrm{mL}$ ) obtained after fermentation of different varieties of Kunun-zaki. Error bars indicate standard deviation of the mean of data obtained from triplicate independent experiments.

of these spices could have altered the $\mathrm{pH}$ of the final kunun-zaki products.

\section{Bacterial quality of kunun-zaki varieties}

The bacterial counts obtained from Kunun-zaki lacking the test spices, (control sample) had the lowest bacterial population $\left(10^{5} \mathrm{CFU} / \mathrm{ml}\right)$ compared to the other kunun-zaki varieties fermented with garlic, cinnamon or nutmeg which had higher microbial load (Fig. 2). Since the organic additives were adequately washed before adding them to substrates prior to fermentation, it is possible that these additives had their own normal flora which might have constituted additional nutritional substrates that further enhanced microbial growth in Kunun-zaki by 10-100 folds. High microbial populations in food products generally indicate low food quality and possible reduction in product shelf-life [27]. Kunun-zaki is a highly nutritious food substrate that may readily support the growth of active microorganisms; thus, accounting for the observed high microbial load in the samples.

DNA sequencing of the $16 \mathrm{~S}$ rRNA gene amplicons

Table 2. 16S rRNA gene sequence identities of bacterial isolates obtained from kunun-zaki varieties.

\begin{tabular}{llclcc}
\hline \multicolumn{1}{c}{ Isolate } & \multicolumn{1}{c}{ Source } & Sequence length & \multicolumn{1}{c}{ Closest relative } & \% Similarity & GenBank accession \\
\hline NOK19 & Kunun $^{\text {a }}$ & 395 & Weissella cibaria & 99.75 & MT023719 \\
NOK21 & Kunun $^{\text {a }}$ & 387 & Enterococcus faecium & 98.44 & MT023720 \\
NOK23 & Kunun $^{\text {a }}$ & 379 & Enterococcus faecium & 90.5 & MT023721 \\
GK29 & Kunun with garlic $_{\text {KK30 }}$ & 370 & Enterococcus faecalis & 99.19 & MT023722 \\
Kunun with garlic & 363 & Enterococcus faecalis & 99.44 & MT023723 \\
GK31 & Kunun with garlic & 386 & Enterococcus sp. & 100 & MT023724 \\
NUTK42 & Kunun with Nutmeg & 371 & Enterococcus sp. & 100 & MT023725 \\
NUTK43 & Kunun with nutmeg & 373 & Enterococcus faecalis & 99.46 & MT023726 \\
NUTK50 & Kunun with nutmeg & 370 & Enterococcus faecalis & 99.46 & MT023727 \\
\hline
\end{tabular}

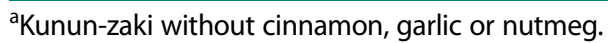


identified bacterial isolates from the kunun-zaki samples as Weissella cibaria, Enterococcus faecium, Enterococcus faecalis and Enterococcus sp. (Table 2). Enterococcus and Weissella species belong to the lactic acid bacteria (LAB) group, and are frequently associated with food spoilage, particularly in raw milk, fermented cereals and vegetables [28]. Weissella cibaria has been reported to be a rare cause of nonfatal human infections and is often considered a contaminant when found in food products [29]. The bacterium $E$. faecalis is an opportunistic pathogen implicated in sepsis, endocarditis, meningitis, headaches, vomiting, increased blood pressure and even allergic reactions [30]. Therefore, the occurrence of these bacteria in the kunun-zaki products analyzed in the present study indicates potential health risk to consumers.

\section{Sensory quality of kunun-zaki varieties}

Sensory assessments of kunun-zaki varieties based on seven-points Hedonic Scale showed that Kunun-zaki (control) had mean value ranging from 1.3 to 1.8 for all sensory attributes, including taste, aroma, appearance and overall acceptability (Table 1). There was significantly different $(p<0.05)$ between the control and test varieties, with the former gaining overall acceptability while Kunun-zaki containing garlic was the least favorite of panelists. However, all varieties fell within the acceptable limit on the Hedonic scale (Table 1), suggesting that the inclusion of the garlic, cinnamon or nutmeg in Kunun-zaki may not lead to consumer rejection of product.

\section{Proximate and amino acid composition of kunun-zaki varieties}

The ash contents of finished products immediately after fermentation ranged between $0.80-4.00 \%$ and $0.7-$ 0.8 after $96 \mathrm{~h}$; crude protein content between 8.1-11.2\% and 4.9-7.4 after $96 \mathrm{~h}$; fat content between $2.90-3.61 \%$ and 1.1-3.7 after $96 \mathrm{~h}$; crude fibre between $5.10-6.30 \%$ and 0.9-2.6 after $96 \mathrm{~h}$, moisture content between 93.394.8\% and 90.0-91.8\% after $96 \mathrm{~h}$; and total carbohydrate between $80.8-84.3 \%$ and $23.7-25.3 \%$ after $96 \mathrm{~h}$ (Table 3). The highest crude protein content was found in kunun-zaki with Nutmeg compared to kunun-zaki with cinnamon and kunun-zaki with garlic. Reasons for this might have been as a result of the additives added and probably because most of it might have been lost during processing [4] much of the proteins in cereals and other crops are usually located in the testa and germ, which are usually sieved off during processing. The \% crude fibre in this study shows that the continuous utilization of the reducing sugars and extractable fat may have led to the increase in the crude fibre content proportion of the kunun-zaki samples. High fibre percentage in this work implies high energy constituent of the kunun-zaki samples, which makes it a more energetic beverage drink. The carbohydrate content of the samples reveals that the kunun-zaki samples analysed was rich in carbohydrate. Carbohydrate is a good source of energy while dietary fiber is very important in human nutrition as it lowers the body cholesterol level; consequently reducing the risk of cardiovascular diseases. Being a thirst-quenching beverage, Kunun-zaki has high moisture content ranging between 55-98\% [31, 32]. The high moisture content may imply greater susceptibility of kunun-zaki to microbial spoilage, as previously suggested by [33, 34]. The moisture was not significantly different among the four kunun-zaki varieties analyzed in this study; therefore, the garlic, nutmeg or cinnamon did not significantly reduce the moisture content of

Table 3. Proximate compositions of kunun-zaki varieties after zero and $96 \mathrm{~h}$ of storage under ambient room temperature.

\begin{tabular}{|c|c|c|c|c|c|c|c|c|c|c|c|c|}
\hline \multirow{3}{*}{$\begin{array}{c}\text { Kunun-zaki } \\
\text { variety }\end{array}$} & \multicolumn{12}{|c|}{ Proximate parameter (\%) } \\
\hline & \multicolumn{2}{|c|}{ Crude protein } & \multicolumn{2}{|c|}{ Fat } & \multicolumn{2}{|c|}{ Ash } & \multicolumn{2}{|c|}{ Crude fiber } & \multicolumn{2}{|c|}{ Moisture } & \multicolumn{2}{|c|}{ Carbohydrate } \\
\hline & $\mathrm{Oh}$ & $96 \mathrm{~h}$ & $\mathrm{Oh}$ & $96 \mathrm{~h}$ & $\mathrm{Oh}$ & $96 \mathrm{~h}$ & $\mathrm{Oh}$ & $96 \mathrm{~h}$ & $\mathrm{Oh}$ & $96 \mathrm{~h}$ & $\mathrm{Oh}$ & $96 \mathrm{~h}$ \\
\hline K1 & 10.1 & 5.5 & 3.6 & 1.1 & 0.8 & 0.7 & 5.8 & 1.4 & 94.8 & 90.0 & 84.3 & 23.7 \\
\hline $\mathrm{K} 2$ & 10.8 & 7.0 & 2.9 & 3.7 & 3.4 & 0.9 & 5.1 & 0.9 & 94.1 & 91.2 & 83.0 & 25.3 \\
\hline K3 & 8.1 & 7.4 & 3.0 & 3.5 & 4.0 & 0.7 & 5.5 & 2.6 & 94.5 & 91.5 & 81.3 & 22.7 \\
\hline K4 & 11.2 & 4.9 & 3.0 & 3.2 & 3.2 & 0.8 & 6.3 & 2.5 & 93.3 & 91.8 & 80.8 & 24.6 \\
\hline
\end{tabular}

K1- Kunun without garlic, cinnamon or garlic; K2- Kunun with cinnamon; K3- Kunun with garlic; K4- Kunun with nutmeg. 
Table 4. Amino acids composition of different varieties of kunun-zaki fermented with organic spices.

\begin{tabular}{|c|c|c|c|c|c|c|c|c|c|c|c|c|c|c|c|c|c|c|c|}
\hline \multirow{2}{*}{$\begin{array}{c}\text { Kunun- } \\
\text { zaki } \\
\text { variety }\end{array}$} & \multicolumn{19}{|c|}{ Amino acids (g/100 g Protein) } \\
\hline & $\begin{array}{l}\text { Ala- } \\
\text { nine }\end{array}$ & $\begin{array}{l}\text { Argi- } \\
\text { nine }\end{array}$ & $\begin{array}{c}\text { Aspar- } \\
\text { tate }\end{array}$ & $\mathrm{Cy}$ & $\begin{array}{l}\text { Gluta- } \\
\text { mate }\end{array}$ & Glycine & $\begin{array}{l}\text { Histi- } \\
\text { dine }\end{array}$ & $\begin{array}{l}\text { Isoleu- } \\
\text { cine }\end{array}$ & Le & e & $\begin{array}{l}\text { Methi- } \\
\text { onine }\end{array}$ & $\begin{array}{l}\text { Phenyl- } \\
\text { alanine }\end{array}$ & Proline & Serine & $\begin{array}{l}\text { Thre- } \\
\text { onine }\end{array}$ & $\begin{array}{l}\text { Trypto- } \\
\text { phan }\end{array}$ & $\begin{array}{l}\text { Tyro- } \\
\text { sine }\end{array}$ & Valine & $\begin{array}{c}\text { TEAA } \\
(\%)\end{array}$ \\
\hline K1 & 5.6 & 3.6 & 5.9 & 5.3 & 20.4 & 3.3 & 2.4 & 4.2 & 10.1 & 2.1 & 2.6 & 7.6 & 8.4 & 5.5 & 3.7 & 8.1 & 3.1 & 5.7 & 50.2 \\
\hline K2 & 6.3 & 3.8 & 6.4 & 6.8 & 18.8 & 3.3 & 2.4 & 4.4 & 9.7 & 2.4 & 2.3 & 6.3 & 8.8 & 5.3 & 3.9 & 8.7 & 3.0 & 5.4 & 49.3 \\
\hline K3 & 6.5 & 3.4 & 6.9 & 4.8 & 19.5 & 4.2 & 2.1 & 4.4 & 9.9 & 2.7 & 2.2 & 7.2 & 8.4 & 5.5 & 3.6 & 1.0 & 2.8 & 5.2 & 41.6 \\
\hline K4 & 6.6 & 3.8 & 6.7 & 4.4 & 19.5 & 3.6 & 3.2 & 4.8 & 9.6 & 2.5 & 2.2 & 7.4 & 8.2 & 4.8 & 3.4 & 9.4 & 2.9 & 5.1 & 51.3 \\
\hline
\end{tabular}

K1- Kunun without garlic, cinnamon or garlic; K2- Kunun with cinnamon; K3- Kunun with garlic; K4- Kunun with nutmeg.

kunun-zaki. However the nutritional content depreciated rapidly after $24 \mathrm{~h}$ in all samples except in kununzaki fermented with garlic whose crude protein and fat content lasted up to $48 \mathrm{~h}$ (Fig. 5).

Three amino acids, namely leucine, proline and glutamate were most abundant in the kunun-zaki samples at concentrations ranging from 9.5 to $20.3 \mathrm{~g} / 100 \mathrm{~g}$ protein (Table 4). Comparatively, Variety K3 had the highest value for total essential amino acid (TEAA) (51.3\%), while variety K2 had the lowest (41.6\%) [35]. Recommended that food materials having TEAA values of $11 \%$ and $26 \%$ were adequate for adults and infant protein supplementations respectively; suggesting that the kunun-zaki reported in this study is rich in protein,
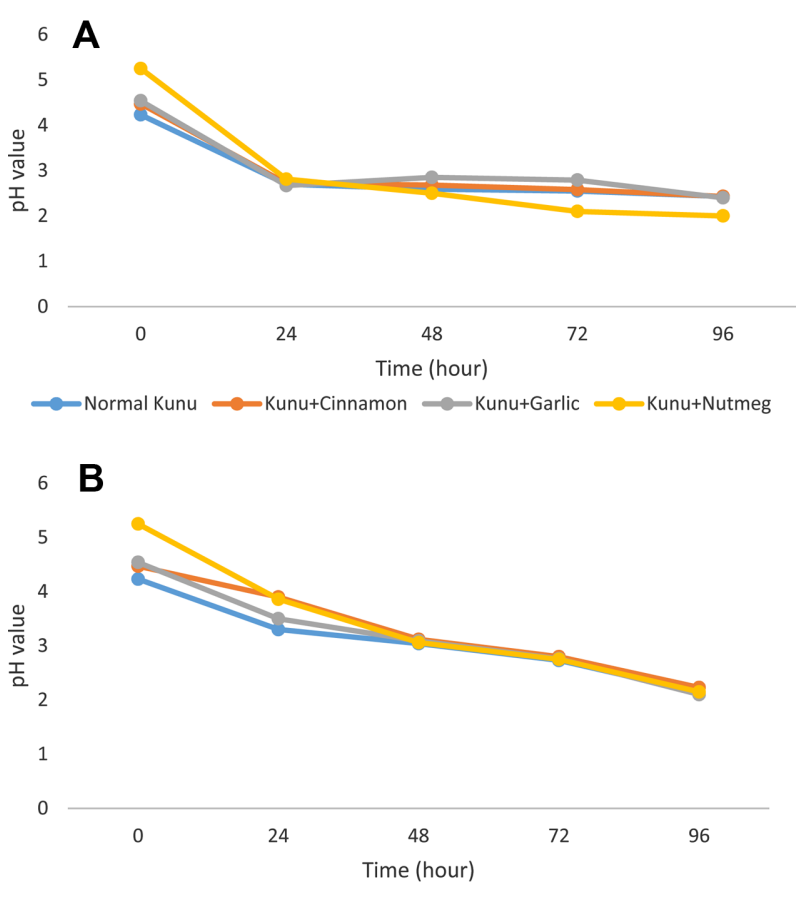

Fig. 3. pH values of kunun-zaki varieties stored under ambient room temperature for 96 hours. regardless of the variety.

\section{Shelf-life of kunun-zaki varieties}

Evaluation of kunun-zaki varieties for 96 h (5 days) of storage under refrigeration or ambient room temperature showed that the $\mathrm{pH}$ values of the final products decreased significantly within the first $24 \mathrm{~h}$ in both refrigerated and unrefrigerated sample. Although the decline was slightly less steep in the refrigerated samples (Fig. 3). The proximate composition of the kunun-zaki

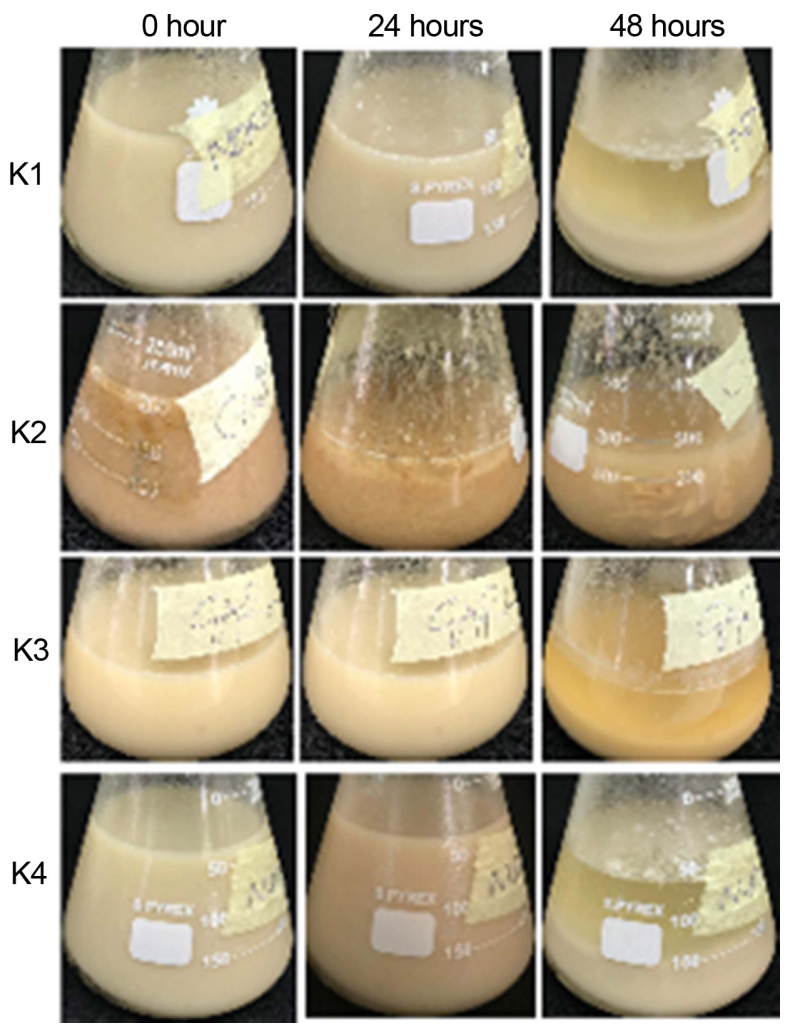

Fig. 4. The four varieties of kunun-zaki at 0 hour, 24 hours and 48 hours stored under room temperature. K1- Normal kunun-zaki, K2- Kunun-zaki with Cinnamon, K3- Kunun-zaki with Garlic, K4- Kunun-zaki with Nutmeg. 


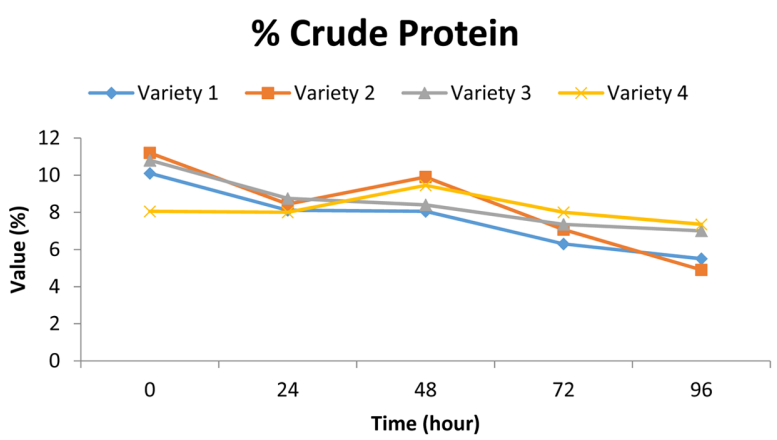

\% Ash

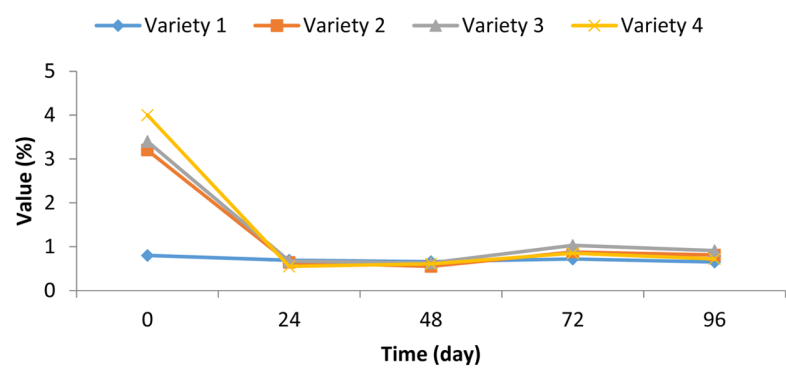

\% Moisture

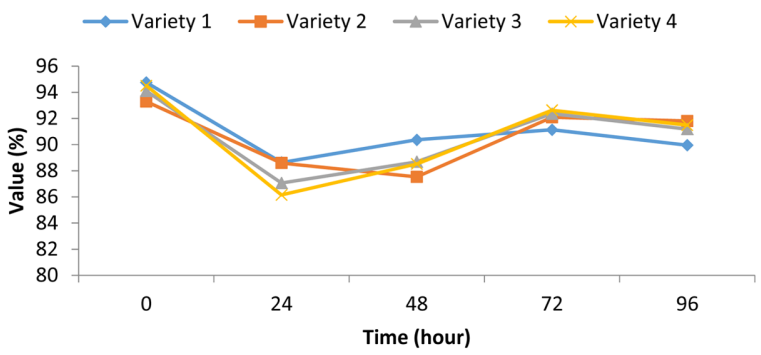

\% Fat

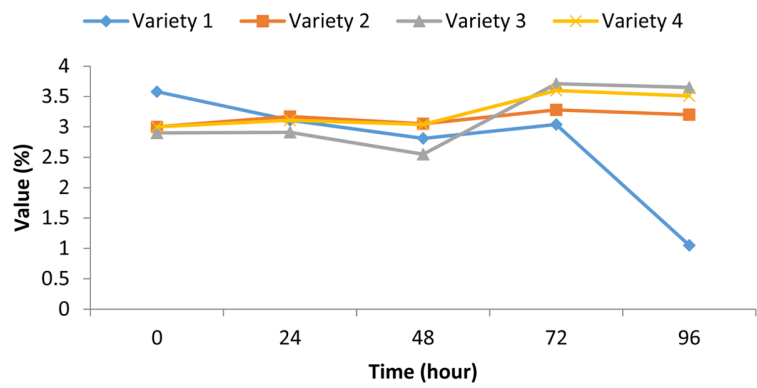

\% Crude Fiber

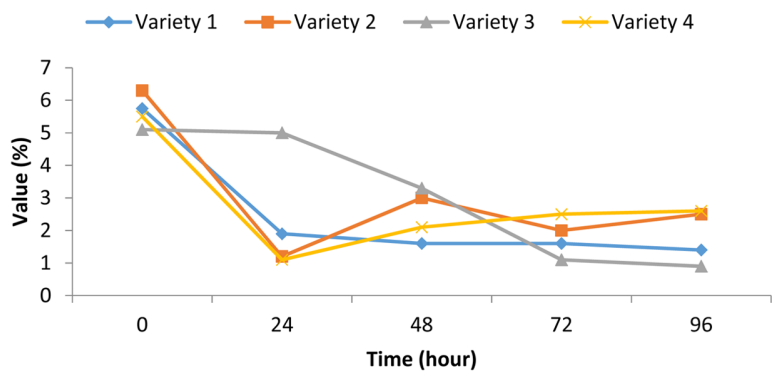

\% Carbohydrates

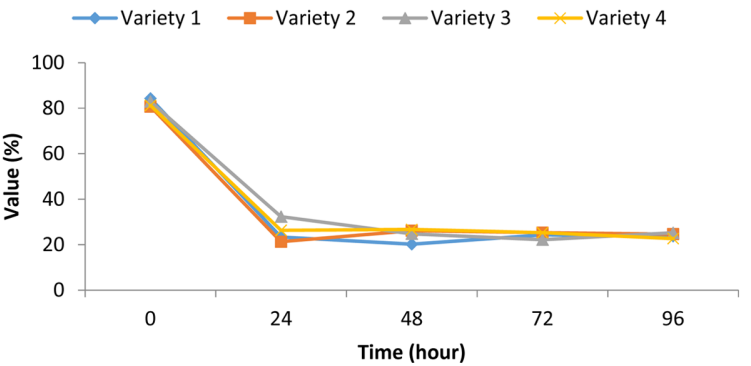

Fig. 5. Proximate composition (Protein, ash, fat, crude fibre, moisture anf carbohydrate) of Kunun-zaki varieties monitored over five days storage at room temperature. Variety 1 - Kunun-zaki without organic additives; Variety 2 - Kunun-zaki with nutmeg; Variety 3 - Kunun-zaki with cinnamon; Variety 4 - Kunun-zaki with garlic.

varieties were also measured throughout the storage period, but only under ambient room temperature, as this was the condition Kunun-zaki are actually marketed. As shown in Table 3, except for the moisture content, the values of all other parameters measured decreased significantly between $0 \mathrm{~h}$ and $96 \mathrm{~h}$. The most pronounced decline was recorded in ash, crude fibre and carbohydrate contents. These results indicated that kunun-zaki stored under room temperature in tropical environment is most nutritionally beneficial when consumed within the first $24 \mathrm{~h}$ after production, regardless of spices used.

Subsequently, the appearance, colour and texture of the variously treated kunun-zaki varieties declined with increase in shelf-life duration (Fig. 4). The color and consistency of kunun-zaki products were also assessed as indicators of quality and spoilage over the $48 \mathrm{~h}$ storage period, as indicated in Fig. 4. Colour deterioration of the samples could have resulted from possible accumulation of microbial metabolic products. The decline in texture of the kunun zaki samples could be attributed to, among other factors, possible increase in microbial load of the product over time.

The proximate composition decreased with increase in keeping time (Fig. 5). The protein content of the samples 
decreased in duration of storage for a period of $98 \mathrm{~h}$. The slight increase in protein content could be due to protein hydrolysis, which involves a consistently active proteinase activity resulting in rapid amino acid production during fermentation. A slight increase in the protein content (4.5\%) was observed in fermented locust bean [36]. The ash content decreased after $24 \mathrm{~h}$ for all the samples except normal kunun whose ash content increased during storage $(98 \mathrm{~h})$. The reduction in the ash content could be as a result of its usage as metabolic nutrients for the growth of microorganisms [32]. The effect of the organic additives on the moisture content was very slight. There was a slight decrease in all samples at $24 \mathrm{~h}$ and $48 \mathrm{~h}$ and an increase again on all samples at $72 \mathrm{~h}$ and $98 \mathrm{~h}$. This could be said to be nonsignificant and could be due to the relatively high level of moisture in the product. The fat content of the four different samples were low compared to the result obtained by [24] and there was an increase as fermentation time increased especially for kunun-zaki with garlic. Dehulling and milling of grains has been shown to reduce the crude fibre content of food products [37]. After storage for $96 \mathrm{~h}$ there was a rapid decrease in carbohydrate content.

\section{Conclusion}

The results revealed that organic spices increased the nutritional content of the kunun-zaki varieties and have potential for application as natural preservatives for enhancing the shelf-life of kunun-zaki. However, garlic may be considered better alternative based on preliminary investigation. The presence of the isolated organisms in kunun-zaki samples analysed could serve as the need to promote awareness about possible health hazards that could arise from poor handling and processing techniques.

\section{Acknowledgments}

The authors thank the sensory panellist for their time and cooperation during the sensory evaluations.

\section{Conflict of Interest}

The authors have no financial conflicts of interest to declare.

\section{References}

1. Aboh Ml, Oladosu P. 2014. Microbiological assessment of kunun-zaki marketed in Abuja Municipal area council (AMAC) in the Federal Capital Territory (FCT), Nigeria. Afr. J. Microbiol. Res. 8: 1633-1637.

2. Adejuyitan J, Adelakun O, Popoola F. 2008. Evaluating the quality characteristics of kunun produced by dry-milled sorghum. Afr. J. Biotechnol. 7: 2244-2247.

3. Gaffa T, Jodeani I, Nkama J. 2002a. Traditional production, consumption and storage of kunun; A non-alcoholic cereal beverage. Plant Foods. Hum. Nutr. 57: 73-81.

4. Akoma O, Jiya E, Mishilia E. 2006. Influence of malting on the nutritional characteristic of Kunun-zaki. Afr. J. Biotechnol. 5: 9961000.

5. Onuorah SL, Adesigun AA, Adeleke JO. 1987. Occurrence of Staphylococci and E. coli form in kunun-zaki and utensils used in its production. J. Food. Agric. 11: 31-34.

6. Essien E, Monago C, Edor E. 2009. Evaluation of the nutritional and microbiology quality of kunun (A cereal based non-alcoholic beverage) in Rivers State, Nigeria. Int. J. Nutr. Well. 10: 1-4.

7. Osuntoki A, Korie F. 2009. Antioxidant activity of whey from fermented milk, fermented with Lactobacillus species from Nigerian fermented foods. J. Food Technol. Biotechnol. 48: 505-511.

8. Oyewole OA, Isah P. 2012. Locally fermented foods in Nigeria and their significance to national economy. J. Rec. Adv. Agric. 1: 92-102.

9. Umaru GA, Tukur IS, Akensire UA, Adamu Z, Bello OA, Shawulu $A H B$, et al. 2014. Micro flora of kunun-zaki and zobo drinks in relation to public health in Jalingo metropolis, North-Eastern Nigeria. Int. J. Food Res. 1: 16-21.

10. Maoura N, Mbaiguinam M, Nguyen HV, Gaillardin C, Pourquie J. 2005. Identification and typing of yeast strains isolated from bili bili, a traditional sorghum beer of Chad. Afr. J. Biotechnol. 4: 646656.

11. Chelule PK, Mokoena MP, Gqaleni N. 2010. Advantages of traditional lactic acid bacteria fermentation of food in Africa. In Current Research, Technology and Education Topics in Applied Microbiology and Microbial Biotechnology (ed), pp. 1160-1167. A Méndez-Vilas.

12. Van der Aa Kühle A, Jesperen L, Glover RLK, Diawawr B, Jakobsen M. 2001. Identification and characterization of Saccharomyces cerevisiae strains isolated from West African sorghum. Yeast $\mathbf{1 8}$ : 1069-1079.

13. Naumova ES, Korshunova IV, Jespersen L, Gennadi I, Naumov Gl. 2003. Molecular genetic identification of Saccharomyces sensu stricto strains from African sorghum beer. FEMS Yeast Res. 3: 177184.

14. Ayandele AA. 2015. Microbiological analyses of hawked kunun and sobo drinks within LAUTECH campus, Ogbomoso, Oyo State, Nigeria. IOSR J. Environ. Sci. Toxicol. Food Tech. 9: 52-56.

15. Alcicek A, Bozkurt M, Cabuk M. 2003. The effect of an essential oil combination derived from selected herbs growing wild in Turkey performance. S. Afr. J. Anim. Sci. 33: 89-94. 
16. Halender IM, Alakomi HI, Latva-Kala K, Mattila-Sandholm T, Pol I, Smid EJ, et al. 1998. Characterization of the action of selected essential oil components on Gram-negative bacteria. J. Agric. Food. Chem. 46: 3590-3595.

17. Lambert RJW, Skandamis PN, Coote PJ, Nychas GJE. 2001. A study of the minimum inhibitory and mode of action of oregano essential oils, thymol and carvacrol. J. Appl. Microbiol. 91: 453462.

18. Dorman HJD, Deans SG. 2000. Antimicrobial agent for plants: antibacterial activity of plants volatile oils. J. Appl. Microbiol. 88: 308-316.

19. Chang ST, Chen PT, Chang SC. 2001. Antibacterial of leaf essential oils and their constituent from Cinnamomum osmophleom. J. Ethnopharmacol. 77: 123-127.

20. Kraig R. 2013. Herbs and spices for improving the gastrointestinal health of the rabbit. In: Proceedings of the 25th Hungarian Conference on Rabbit production. pp. 53-68. Kaposvar, Hungary.

21. Gaffa TIA, Jideani I, Nkama I. 2002b. Nutrients and sensory qualities of kunun-zaki from different saccharifying agents. Int. J. Food Sci. Nutr. 53: 109-115.

22. AOAC. 2006. Official Methods of Analysis of AOAC International. (18th Ed.). AOAC International, Gaithersburg, MD., USA, ISBN13: 978-0935584752.

23. Larmond E. 1977. Laboratory Methods for Sensory Evaluation of Food. Research Branch, Canada Department of Agriculture. 1637: 19-63.

24. Nkama I, Agarry OO, Akoma O. 2010. Sensory and nutritional quality characteristics of powdered kunun-zaki; A Nigerian fermented cereal beverage. Afr. J. Food Sci. 4: 364-370.

25. Obanewo OS, Zidon G. 2008. Production and evaluation of powered kunun-zaki using fluidized bed dryer. Nig. Food. J. 21: 144-146.

26. Obadina AO, Oyewole OB, Awojobi TM. 2008. Effect of steeping time of milled grains on the quality of Kunun-Zaki (a Nigerian beverage). Afr. J. Food Sci. 2: 033-036.

27. Seema R. 2015. Food spoilage: Microorganisms and their prevention. Asian J. Plant Sci. Res. 5: 47-56.

28. Tannock GW, Cook G. 2002. Enterococci as members of the intestinal microflora of humans. In: The Enterococci, Pathogenesis, Molecular Biology and Antibiotics Resistance (Gilmore, M. S. ed), pp. 101-132. ASM, Washington, DC. USA.

29. Olano A, Chua J, Schroeder S, Minari A, La Salvia M, Hall G. 2001. Weissella confusa (basonym: Lactobacillus confusus) bacteremia: a case report. J. Clin. Microbiol. 39: 1604-1607.

30. Giraffe G. 2002. Enterococci from foods. FEMS Microbiol. Rev. 26: 163-171.

31. Giese G. 1995. Measuring physical properties of foods. J. Food Technol. 2: 49-51.

32. Amusa NA, Ashaye OA. 2009. Effect of processing on nutritional, microbiological and sensory properties of kunun-zaki (a sorghum based non-alcoholic Beverage) Widely Consumed in Nigeria. Pakistan J. Nutr. 8: 288-292.

33. Battey AS, Duffy S, Schaffner DW. 2002. Modelling Yeast spoilage in cold-filled ready-to- drink beverages with Saccharomyces cerevisiae, Zygosaccharomyces bailii and Candida lipolytica. Appl. Environ. Microbiol. 68: 1901-1906.

34. El-mahmood AM, Doughari JH. 2007. Microbial quality assessment of kunun-zaki beverage sold in Girei town of Adamawa State Nigeria. Afr. J. Food Sci. 1: 11-15.

35. FAO/WHO/UNU. 1985. Energy and protein requirements. Technical report series. No. 275, Geneva, 204.

36. Odunfa SA. 1985. African fermented foods In: Microbiology of Fermented Foods. Vol.2. B.J.B. Wood (Ed.) pp. 155-191. London: Elsevier Applied Science.

37. Adeyemi IA. 1983. Dry milling of sorghum for ogi manufacture. J. Cereals Sci. 1:221-226. 